DOI : https://doi.org/10.24843/JFU.2021.v10.i01.p03

pISSN: 2301-7716; eISSN: 2622-4607

Jurnal Farmasi Udayana, Vol 10, No 1, Tahun 2021, 23-30

\title{
Penentuan Kadar Flavonoid Total Ekstrak Etanol Jamur Susu Harimau (Lignosus rhinocerus)
}

\author{
Sari DY ${ }^{1}$, Widyasari $\mathbf{R}^{\mathbf{1}}$, Taslima $\mathbf{A N}^{\mathbf{1}}$ \\ ${ }^{\text {I}}$ Program Studi D III Farmasi, Akademi Farmasi Yarsi, Jalan Panglima Aim No. 2, Pontianak, \\ Indonesia 78232
}

*E-mail: dinayuspitasari7@gmail.com

Riwayat artikel: Dikirim: 19/11/2020; Diterima: 30/12/2020, Diterbitkan: 1/07/2021

\begin{abstract}
Tiger milk mushroom (Lignosus rhinocerus) is a plant that has traditionally been used as a medicine in the interior of West Kalimantan, especially in Kapuas Hulu. One of the phytochemical constituents contained is flavonoids (flavones and flavanones). This study aims to determine the total flavonoid content of ethanol extract of tiger milk mushroom. The simplicia of tiger milk mushroom was macerated using 96\% ethanol. Phytochemical screening for the presence of flavonoids the extract using magnesium and amyl alcohol powder. Determination of total flavonoid content in ethanol extract of tiger milk mushrooms was carried out by UV-Vis spectrophotometry using the colorimetric method $\left(\mathrm{AlCl}_{3}\right)$ at $\lambda 410 \mathrm{~nm}$ and expressed as total flavonoids in quercetin equivalent. The results showed that total flavonoid content of ethanol extract is $33.041 \mathrm{mgEQ} / \mathrm{g}$ extract. Ethanol extract of tiger milk mushroom which contains flavonoids is potential as a source of natural antioxidants and potential to be developed in medicinal and cosmetic products.
\end{abstract}

Keywords: Colorimetry, tiger milk mushroom, total flavonoid content

\begin{abstract}
ABSTRAK
Jamur susu harimau (Lignosus rhinocerus) merupakan tanaman yang digunakan dalam pengobatan tradisional di pedalaman Kalimantan Barat terutama di Kapuas Hulu. Salah satu konstituen fitokimia yang terkandung adalah flavonoid (flavon dan flavanon). Penelitian ini bertujuan untuk menentukan kadar flavonoid total pada ekstrak etanol jamur susu harimau. Simplisia jamur susu harimau dimaserasi menggunakan etanol $96 \%$. Skrining fitokima terhadap keberadaan flavonoid dalam ekstrak menggunakan serbuk magnesium dan amil alkohol. Penentuan kadar flavonoid total pada ekstrak etanol jamur susu harimau dilakukan secara spektrofotometri UV-Vis dengan metode kolorimetri $\left(\mathrm{AlCl}_{3}\right)$ pada $\lambda 410 \mathrm{~nm}$ dan dinyatakan sebagai flavonoid total dalam ekuivalen kuersetin (EQ). Kadar flavonoid total pada ekstrak etanol jamur susu harimau adalah sebesar 33,041 mgEQ/g ekstrak. Ekstrak etanol jamur susu harimau yang mengandung flavonoid berpotensi sebagai sumber antiooksidan alami dan potensial untuk dikembangkan dalam produk obat dan kosmetik.
\end{abstract}

Kata kunci: Jamur susu harimau, kadar flavonoid total, kolorimetri

\section{PENDAHULUAN}

Jamur Susu Harimau (Lignosus
rhinocerus) merupakan tanaman
tradisional yang berasal dari pedalaman
Kalimantan Barat terutama di Kapuas
Hulu. Tanaman ini hanya dapat ditemukan

di wilayah geografis tertentu yang meliputi Cina Selatan, Thailand, Malaysia, Indonesia, Filipina, Papua Nugini, Selandia Baru, dan Australia. Jamur Susu Harimau merupakan tumbuhan yang dianggap sebagai obat tradisional yang sudah mulai 
DOI : https://doi.org/10.24843/JFU.2021.v10.i01.p03

pISSN: 2301-7716; eISSN: 2622-4607

Jurnal Farmasi Udayana, Vol 10, No 1, Tahun 2021, 23-30

langka dikarenakan pertumbuhannya memakan waktu yang cukup lama. Menurut Tan et al (2009) bagian jamur yang bermanfaat secara medis adalah sklerotia.

Secara tradisional jamur susu harimau telah digunakan oleh tabib melayu untuk mengobati kanker darah, kanker serviks, penyakit tukak usus, penyakit ginjal, dan pembengkakan di sekitar mata dan tubuh; praktisi pengobatan Tiongkok tradisional juga menggunakannya untuk mengobati kelelahan, asma, meningkatkan kesehatan, memperkuat sistem imunologi tubuh serta sebagai antioksidan (Tan et al., 2015). Berdasarkan penelitian limiah, jamur susu harimau memiliki manfaat dalam bidang farmasi, diantaranya: sebagai penghambat glikasi pada diabetes (Yap et $a l, 2018$ ), aktivitas antiasma (Jonathan et al., 2016), aktivitas antikoagulan dan fibrinolitik (Lee et al., 2005), antiobesitas dan hepatoprotektif (Hoe, 2014), antiinflamasi (Lee et al., 2012), antimikroba (Moharnaji et al, 2012), aktivitas menghambat human papilloma virus (HPV) (Abdullah et al., 2010), aktivitas sitotoksik (Marzouk, 2016), dan aktivitas immune modulatory (Wong and Cheung, 2009).

\section{Peneltian}

sebelumnya menunjukkan adanya konstituen fitokimia seperti alkana, asam-asam lemak, benzena, senyawa fenol, asam dekarboksilat, dan flavonoid (Jonathan et al., 2016). Senyawa metabolit sekunder yang menjadi objek utama dalam penelitian ini adalah flavonoid. Flavonoid merupakan sumber antioksidan, memiliki cincin aromatik yang mengandung setidaknya satu gugus hidroksil (Hasmi et al., 2016). Flavonoid merupakan pendonor elektron yang baik karena gugus hidroksilnya yang berperan sebagai antioksidan (Aryal et al., 2019).

Analisis kuantitatif flavonoid total dapat dilakukan dengan menggunakan metode kolorimetri menggunakan spektrofotometer UV-Visibel. Metode kolorimetri digunakan untuk penetapan kadar flavonoid yaitu dengan menggunakan pereaksi $\mathrm{AlCl}_{3}$. Terjadi kompleks tahan asam antara gugus hidroksi dan keton yang bertetangga dengan pereaksi $\mathrm{AlCl}_{3}$ dan membentuk kompleks tidak tahan asam dengan gugus ortohidroksi pada flavonoid. Oleh karena itu, pereaksi $\mathrm{AlCl}_{3}$ digunakan untuk mendeteksi kedua gugus tersebut (Azizah, 2014). Prinsip penetapan kadar flavonoid dengan metode kolorimetri $\mathrm{AlCl}_{3}$ adalah terbentuknya kompleks antara $\mathrm{AlCl}_{3}$ dengan gugus keto pada atom C-4 dan juga dengan gugus hidroksil pada atom C-3 atau C-4 yang bertetangga dari flavon dan flavonol (Parthasarathi and Park, 2015).

Penelitian mengenai aktivitas
antioksidan jamur susu harimau
sebelumnya menggunakan ekstrak air
dingin, dan ekstrak metanol, dimana
senyawa antioksidan yang diuji adalah
komponen metabolit primer asam oleat dan
asam linoleat (Nallathamby et al., 2016)
dan senyawa metabolit sekuder golongan
fenolik (Yap et al., 2018). Oleh karena,
peneliti tertarik untuk melakukan
penetapan kadar flavonoid total yang
terkandung dalam ekstrak etanol jamur
susu harimau (Lignosus rhinocerus).

\section{BAHAN DAN METODE}

\section{Bahan dan Alat}

Bahan-bahan yang digunakan dalam penelitian ini yaitu jamur susu harimau (Lignosus rhinocerus) yang diperoleh dari Kabupaten Kapuas Hulu, Kalimantan Barat, etanol 96\%, etanol pro analisis (Merck), asam asetat, asam klorida, serbuk magnesium, quersetin, dan $\mathrm{AlCl}_{3}$. 
DOI : https://doi.org/10.24843/JFU.2021.v10.i01.p03

pISSN: 2301-7716; eISSN: 2622-4607

Jurnal Farmasi Udayana, Vol 10, No 1, Tahun 2021, 23-30

Alat-alat yang digunakan pada penelitian ini adalah ayakan, blender, neraca analitik (Sartorius BL 210S), batang pengaduk, gelas ukur, toples kaca bertutup, magnetic stirrer, dry cabinet, rotary evaporator (Dragon LAB RE-10 Pro), gelas beaker, alumunium foil, dan spektrofotometer UV-Visibel (Shimadzu Uv-1700 Pharmaspec).

\section{Metode}

\section{Sub Metode 1 Pengumpulan dan Pengolahan Sampel}

Jamur Susu Harimau diambil
bagian bawah (sklerotia). Sampel
kemudian disortasi basah, dicuci, disortasi
kering, dirajang, dikeringkan
menggunakan dry cabinet pada suhu $40^{\circ} \mathrm{C}$,
dan diblender.

\section{Sub Metode 2 Pembuatan Ekstrak Jamur susu harimau (Lignosus rhinocerus)}

Ekstraksi menggunakan metode maserasi dengan cara serbuk simplisia bagian sclerotium jamur susu harimau $(881,31 \mathrm{~g})$ dimaserasi menggunakan etanol $96 \%$. Ekstraksi dilakukan selama $4 \times 24$ jam pada suhu kamar. Maserat yang didapat dikumpulkan kemudian dipekatkan menggunakan rotary vaccum evaporator (Parthasarathi and Park, 2015). Ekstrak pekat yang diperoleh sebanyak 34,78 g, dengan rendemen sebesar $1,58 \%$.

\section{Sub Metode 3 Skrining Fitokimia}

Sejumlah ekstrak jamur susu harimau ditambahkan serbuk magnesium $0,1 \mathrm{mg}$ dan $0,4 \mathrm{~mL}$ amil alkohol (campuran asam klorida 37\% dan etanol 95\% dengan volume yang sama) dan $4 \mathrm{~mL}$ alkohol kemudian campuran dikocok. Pembentukan warna merah, kuning atau jingga pada lapisan amil alkohol menunjukkan hasil flavonoid (Rebaya et al., 2015).

\section{Sub Metode 4 Penentuan Kadar Flavonoid Total Dengan Metode Kolorimetri}

Penentuan kadar flavonoid total pada ekstrak etanol jamur susu harimau dilakukan secara spektrofotometri UV-Vis dengan metode kolorimetri $\left(\mathrm{AlCl}_{3}\right)$ pada $\lambda$ $410 \mathrm{~nm}$ dan dinyatakan sebagai flavonoid total dalam ekuivalen kuersetin (EQ) (Rebaya et al., 2019).

1. Penentuan Panjang Gelombang Maksimum Kuersetin.

Sebanyak $10 \mathrm{mg}$ quersetin dilarutkan dalam $10 \mathrm{~mL}$ etanol (1000 ppm). Kemudian diencerkan menjadi konsentrasi 60 ppm. Sebanyak $1 \mathrm{~mL}$ larutan kuersetin 60 ppm dipipet kemudian ditambahkan $1 \mathrm{~mL} \mathrm{AlCl}_{3}$ $2 \%$ dan $8 \mathrm{~mL}$ asam asetat $5 \%$, diinkubasi selama 30 menit. Absorbansi diukur panjang gelombang 400-800 nm (Ipandi, dkk., 2016).

2. Pembuatan Kurva Standar quersetin. Ditimbang quersetin sebanyak $10 \mathrm{mg}$ dilarutkan dengan etanol $10 \mathrm{~mL}$ (1000 ppm). Dibuat variasi konsentrasi 20 ppm, 40 ppm, 60 ppm, 80 ppm dan 100 ppm. dipipet masing-masing sejumlah $1 \mathrm{~mL}$ dari larutan standar ditambah dengan 1 $\mathrm{mL} \mathrm{AlCl}_{3} 2 \%$, dan $8 \mathrm{~mL}$ asam asetat $5 \%$. Setelah itu diinkubasi selama 30 menit, absorbansi diukur dengan spektrofotometer UV-Vis pada $\lambda$ maksimum kuersetin $(410 \mathrm{~nm})$, dibuat kurva kalibrasi dengan menghubungkan nilai serapan sebagai koordinat (Y) dan konsentrasi larutan standar absis (X) (Ipandi, dkk., 2016).

3. Penentuan Kadar Flavonoid Total Ekstrak Etanol Jamur Susu Harimau. $25 \mathrm{mg}$ ekstrak etanol jamur susu harimau dilarutkan dengan $10 \mathrm{~mL}$ etanol. Kemudian diaduk 
DOI : https://doi.org/10.24843/JFU.2021.v10.i01.p03

pISSN: 2301-7716; eISSN: 2622-4607

Jurnal Farmasi Udayana, Vol 10, No 1, Tahun 2021, 23-30

menggunakan magnetic stirrer dengan kecepatan 300 rpm, ditambah etanol sampai diperoleh larutan sebanyak $50 \mathrm{~mL}$ (500 ppm). Sampel dipipet $1 \mathrm{~mL}$, kemudian ditambahkan $1 \mathrm{~mL} \mathrm{AlCl}_{3} 2 \%$, dan $8 \mathrm{~mL}$ asam asetat $5 \%$, Setelah itu diinkubasi selama 30 menit, absorbansi (410 $\mathrm{nm})$ diukur dengan spektrofotometer UV-Vis pada $\lambda 40 \mathrm{~nm}$. Setelah diperoleh absorbansi ekstrak etanol jamur susu harimau, dihitung kadar flavonoid total (Ipandi, dkk., 2016). Pengujian dilakukan secara triplo. Kadar flavonoid dapat dihitung menggunakan rumus :

$F=\frac{c \times V \times f \times 10^{-6}}{m} \times 100 \%$

Keterangan: F: jumlah flavonoid metode $\mathrm{AlCl} 3$; c: kesetaraan quersetin $(\mu \mathrm{g} / \mathrm{mL})$; $\mathrm{V}$ : volume total ekstrak; f: faktor pengenceran; dan $\mathrm{m}$ : berat sampel $(\mathrm{g})$ (Azizah, dkk., 2014).

\section{HASIL}

\section{Pengumpulan dan Pengolahan Sampel}

Jamur susu harimau $(2.203,275 \mathrm{~g})$ dibersihkan kemudian dikeringkan menggunakan dry cabinet sehingga didapatkan simplisia kering kayu secang dengan kadar air sebesar $40 \%$. Massa kering serbuk kasar simplisia jamur susu harimau adalah $881,31 \mathrm{~g}$.

\section{Proses Ekstraksi dan Pemeriksaan Karakteristik Ekstrak Etanol Jamur Susu Harimau}

Ekstraksi simplisia jamur susu harimau dilakukan dengan cara maserasi menggunakan pelarut etanol $96 \%$. Ekstrak kental etanol yang diperoleh adalah sebanyak 34,78 g dengan rendemen sebesar $1,58 \%$.

\section{Skrining Fitokimia}

Ekstrak jamur susu harimau ditambahkan serbuk magnesium $0,1 \mathrm{mg}$ dan 0,4 $\mathrm{mL}$ amil alkohol (campuran asam klorida $37 \%$ dan etanol $95 \%$ dengan volume yang sama) dan $4 \mathrm{~mL}$ alkohol kemudian campuran dikocok (Rebaya et al., 2015), menghasilkan warna larutan jingga.

\section{Penetapan Kadar flavonoid Total Ekstrak Etanol Jamur Susu Harimau}

Analisis kadar flavonoid total menggunakan metode kolorimetri dan spektrofotometri UV-Vis. Standar yang digunakan adalah quersetin. Pengukuran panjang gelombang maksimum dilakukan pada rentang panjang gelombang 400-800 nm. Panjang gelombang maksimum quersetin hasil pengukuran adalah pada panjang gelombang $410 \mathrm{~nm}$. Panjang gelombang maksimum tersebut digunakan untuk menentukan kurva seri quersetin dan kadar flavonoid total pada sampel ekstrak jamur susu harimau. Pada penentuan kurva baku quersetin, dibuat quersetin dengan seri konsentrasi 20, 40, 60, 80, dan 100 $\mu \mathrm{g} / \mathrm{mL}$.

Hasil yang didapat dari pembuatan kuva kaliberasi adalah persamaan regresi linier $y=0,00558 x-0,00765$ dengan koefisien determinasi $\left(\mathrm{r}^{2}\right)$ sebesar 0,99088.

Penetapan kadar flavonoid total dilakukan menggunakan spektrofotometer UV-Vis, dengan memasukkan nilai absorbansi sampel ke dalam persamaan kurva baku quersetin. 
DOI : https://doi.org/10.24843/JFU.2021.v10.i01.p03

pISSN: 2301-7716; eISSN: 2622-4607

Jurnal Farmasi Udayana, Vol 10, No 1, Tahun 2021, 23-30

Tabel 1. Kadar Flavonoid Total Ekstrak Etanol Jamur Susu Harimau

\begin{tabular}{ccccc}
\hline Sampel & Replikasi & Absorbansi & $\begin{array}{c}\text { Konsentrasi } \\
\text { (mgEQ/g } \\
\text { ekstrak) }\end{array}$ & $\begin{array}{c}\text { Rata-rata kadar } \\
\text { flavonoid total } \\
\text { (mgEQ/g ekstrak) }\end{array}$ \\
\hline \multirow{2}{*}{ Ekstrak etanol } & 1 & 0,087 & 33,822 & \\
& 2 & 0,083 & 32,554 & $33,041 \pm 0,683$ \\
\hline
\end{tabular}

\section{PEMBAHASAN}

\section{Pengumpulan dan Pengolahan Sampel}

Sortasi basah dilakukan untuk memisahkan kotoran atau bahan-bahan asing yang menempel. Pengeringan dilakukan untuk mengurangi kadar air sampel. Hal ini dilakukan untuk menghentikan reaksi enzimatis sehingga mengurangi resiko tumbuhnya jamur selama penyimpanan yang dapat menurunkan mutu simplisia. Sampel yang telah kering kemudian dirajang menjadi ukuran yang lebih kecil, setelah itu dilanjutkan dengan penghalusan menggunakan blender sampai didapat serbuk kasar jamur susu harimau, tujuannya adalah untuk memperkecil ukuran partikel simplisia sehingga memperluas kontak simplisia dengan pelarut saat proses ekstraksi agar proses ekstraksi optimal. Massa kering serbuk kasar simplisia jamur susu harimau adalah $881,31 \mathrm{~g}$.

\section{Proses Ekstraksi dan Pemeriksaan Karakteristik Ekstrak Etanol Jamur Susu Harimau}

Hasil ekstraksi simplisia jamur susu harimau dengan cara maserasi menggunakan pelarut etanol $96 \%$ dan setelah dipekatkan menghasilkan ekstrak dengan karakteristik warna hijaukecoklatan, berbau khas, dan berbentuk ekstrak pekat.

\section{Skrining Fitokimia}

Hasil skrining ekstrak etanol jamur susu harimau memberikan hasil pembentukan warna jingga menunjukkan hasil positif mengandung senyawa flavonoid (Syafitri, dkk., 2014).

\section{Penetapan Kadar flavonoid Total Ekstrak Etanol Jamur Susu Harimau}

Analisis kadar flavonoid total merupakan pengukuran total flavonoid yang terkandung di dalam sampel. Metode yang digunakan adalah kolorimetri dan spektrofotometri UV-Vis. Pereaksi $\mathrm{AlCl}_{3}$ digunakan untuk mendeteksi gugus hidroksi dan keto yang bertetangga dan gugus otro-hidroksi. $\mathrm{AlCl}_{3}$ menyebabkan terjadinya pergeseran spektrum ultraviolet pada flavonoid. Prinsip penetapan kadar flavonoid metode alumunium klorida adalah terjadinya pembenetukan kompleks antara alumunium klorida dengan gugus keto pada atom C-4 dan gugus hidroksi pada atom C-3 atau C-5 yang bertetangga dari golongan flavon dan flavonol (Sugrani, 2009).

Standar yang digunakan adalah quersetin, karena quersetin merupakan flavonoid golongan flavonol yang memiliki gugus keto pada atom $\mathrm{C}-4$ dan juga gugus hidroksil pada atom C-3 dan C5 yang bertetangga (Azizah, dkk., 2014). Persyaratan standar flavonoid yang digunakan adalah harus mengandung gugus hidroksi pada posisi karbon ketiga, ikatan rangkap ganda antara karbon posisi dua dan tiga, gugus karbonil pada posisi karbon keempat dan gugus polihidroksi 
DOI : https://doi.org/10.24843/JFU.2021.v10.i01.p03

pISSN: 2301-7716; eISSN: 2622-4607

Jurnal Farmasi Udayana, Vol 10, No 1, Tahun 2021, 23-30

pada dua cincin aromatik (Sugrani, 2009).

Pengukuran panjang gelombang maksimum dilakukan pada rentang panjang gelombang 400-800 nm. Panjang gelombang maksimum quersetin hasil pengukuran adalah pada panjang gelombang $410 \mathrm{~nm}$. Panjang gelombang maksimum tersebut digunakan untuk menentukan kurva seri quersetin dan kadar flavonoid total pada sampel ekstrak jamur susu harimau.

Pada penentuan kurva baku quersetin, dibuat quersetin dengan seri konsentrasi 20, 40, 60, 80, dan $100 \mu \mathrm{g} / \mathrm{mL}$. kurva kaliberasi digunakan untuk mencapai ketelusuran pengukuran, menentukan kebenaran nilai yang ditunjukkan instrumen dan sampel yang diukur. Kurva kaliberasi diperoleh dengan membuat larutan standar quersetin dengan tujuan untuk mengukur tingkat ketelitian data yang diperoleh (Ahmad, dkk., 2015).

Hasil yang didapat dari pembuatan kuva kaliberasi adalah persamaan regresi linier $\mathrm{y}=0,00558 \mathrm{x}-0,00765$ dengan koefisien determinasi $\left(\mathrm{r}^{2}\right)$ sebesar 0,99088 . Besarnya linearitas ini mendekati nilai satu, sehingga dapat dikatakan bahwa absorbansi merupakan fungsi yang besarnya berbanding lurus dengan konsentrasi dan mengikuti persamaan regresi linier.

Penetapan kadar flavonoid total dilakukan terhadap ekstrak etanol jamur susu harimau. Metode yang digunakan adalah metode kolorimetri. $\mathrm{AlCl}_{3}$ berfungsi membentuk kompleks dengan orto hidroksi maupun hidroksi keton, sementara penambahan asam asetat dimaksudkan untuk menguraikan kembali kompleks karena Al tak stabil pada orto hidroksi dan hidroksi keton (Suhendi, dkk., 2011). Pada penetapan kadar flavonoid, penambahan asam asetat adalah untuk mendeteksi adanya gugus 7-hidroksil sedangkan perlakuan inkubasi selama 30 menit yang dilakukan sebelum pengukuran dimaksudkan agar reaksi berjalan sempurna, sehingga memberikan intensitas warna yang maksimal (Azizah, dkk., 2014).

Penetapan kadar flavonoid total dilakukan menggunakan spektrofotometer UV-Vis, dengan memasukkan nilai absorbansi sampel ke dalam persamaan kurva baku quersetin.

\section{KESIMPULAN}

Kadar flavonoid total pada sampel ekstrak etanol jamur susu harimau adalah sebesar 33,041 mgEQ/g ekstrak. Penelitian ini dapat dilanjutkan dengan pengembangan sediaan obat dan kosmetik menggunakan ekstrak etanol jamur susu harimau.

\section{UCAPAN TERIMAKASIH}

Peneliti mengucapkan terimakasih kepada Akademi Farmasi Yarsi Pontianak sebagai pemberi dana penelitian dan atas kontribusinya.

\section{DAFTAR PUSTAKA}

Tan, W. C., Kuppusamy, U. R., Phan, C.W., Tan, Y.S., Raman, J., Anuar, A. M. (2015). Ganoderma neojaponicum Imazeki revisited: domestication study and antioxidant properties of its basidiocarps and mycelia. Sci. Rep. 5(12). 515. doi: 10.1038/srep12515.

Yap, H. Y., Tan, N. H, Ng, S. T., Tan, C. S, \& Fung, S. Y. (2018) Inhibition of Protein Glycation by Tiger Milk Mushroom [Lignosus rhinocerus (Cooke) Ryvarden] and Search for Potential Anti-diabetic Activity-Related Metabolic Pathways by Genomic and Transcriptomic Data Mining. Front. Pharmacol. 9(103). 103-105. doi: 10.3389/fphar.2018.00103. 
DOI : https://doi.org/10.24843/JFU.2021.v10.i01.p03

pISSN: 2301-7716; eISSN: 2622-4607

Jurnal Farmasi Udayana, Vol 10, No 1, Tahun 2021, 23-30

Johnathan, M., Gan, S. H., Ezumi, M. F. W., Faezahtul, A. H., and Nurul, A. A. (2016). Phytochemical profiles and inhibitory effects of Tiger Milk mushroom (Lignosus rhinocerus) extract on ovalbumin-induced airway inflammation in a rodent model of asthma. BMC Complement. Alternat. Med. 16(167). 1-3. doi: 10.1186/s12906-016-1141-x.

Lee, S. Y., Kim, J. S., Kim, J. E., Sapkota, K., Shen, M. H., Kim, S. (2005). Purification and characterization of fibrinolytic enzyme from cultured mycelia of Armillaria mellea. Prot. Expr. Pur. 43, 10-17. doi: 10.1016/j.pep.2005.05.004.

Hoe, T. L. (2014). Lignosus rhinocerus Attenuated High Fat Diet Induced NonAlcoholic Fatty Liver. National Chung Hsing University.

Lee, S. S., Tan, N. H., Fung, S. Y., Tan, C. S., Ng, S. T., and Sim, S.M. (2012). Antiinflammatory activity of Lignosus rhinocerus (tiger milk mushroom) sclerotia. in Abstracts of the 18th Congress of the International Society for Mushroom Science (Beijing), 150151.

Mohanarji, S. Dharmalingam, S., Kalusalingam, A. 2012. Screening of Lignosus rhinocerus Extracts as Antimicrobial Agents Against Selected Human Pathogens. Journal of Pharmaceutical and Biomedical Sciences (JPBMS). 18(11). 1-3.

Abdullah, N., Wahab, A. I. A., Lau, B. F., Abidin, N. Z., \& Aminudin, N. (2010). Anti-cervical cancer activity and SELDI-TOF-MS analysis of proteins from Lignosus rhinocerus (Tiger's Milk Mushroom) grown in stirred tank reactor. Proceedings of the Fifth International Peptide Symposium.

Marzouk, M. M. 2016. Flavonoid Constituents And Cytotoxic Activity Of Erucaria Hispanica (L.) Druce
Growing Wild In Egypt. Arabian Journal Of Chemistry. 9(1). 411415.

Wong, K. H., and Cheung, P. C. K. (2009).

Sclerotia: emerging functional food derived from mushrooms in Mushrooms as Functional Foods, ed P. C. K. Cheung (111-146). Hoboken, NJ: JohnWiley \& Sons, Inc.

Hasmi, N. A. H., Nordin, N., Kumar, Y., Lani, N., Fazil, F. N. M., Aizad, S., Abidin, N. Z., Zubairi, S. I. 2016. Analysis of Flavonoids in Commercially Available Lignosus Rhinocerus Dried Powder. Extract by Reversed-Phase High Performance Liquid Cromatograph (RP-HPLC). International Future Scientis Conference. Universiti Kebangsaan Malaysia (UKM).

Aryal, S., Baniya, M. K., Danekhu, K., Kunwar, P., Gurung, R., \& Koirala, N. 2019. Total Phenolic Content, Flavonoid Content and Antioxidant Potential of Wild Vegetables from Western Nepal. Jurnal Plants., 8(96). 12-13. doi:10.3390/plants8040096.

Azizah, D. N., Kumolowati, E.,

Faramayuda, F. 2014. Penetapan

Kadar Flavonoid Metode $\mathrm{AlCl}_{3}$ Pada Ekstrak Metanol Kulit Buah Kakao (Theobroma cacao L.). Kartika Jurnal Ilmiah Farmasi. 2(2). 47.

Parthasarathi, S., and Park, Y. K., 2015. Determination of total phenolics, flavonoid contents and antioxidant activity of different mBHT fractions: A polyherbal medicine. Pakistan journal of pharmaceutical sciences. 28(6). 2162-2164.

Rebaya, A., Belghith, S. I., Baghdikian, B., Leddet, V. M., Mabrouki, F., Olivier, E.,, Cherif, J. K., Ayadi, M. T. 2014. Total Phenolic, Total Flavonoid, Tannin Content, and Antioxidant Capacity of Halimium halimifolium (Cistaceae). Journal of Applied Pharmaceutical 


\section{Sari, dkk}

DOI : https://doi.org/10.24843/JFU.2021.v10.i01.p03

pISSN: 2301-7716; eISSN: 2622-4607

Jurnal Farmasi Udayana, Vol 10, No 1, Tahun 2021, 23-30

Science. 5(1). 52-57. doi: 10.7324/JAPS.2015.50110.

Ipandi, I., Triyasmono, L., dan Prayitno, B.

2016. Penentuan Kadar Flavonoid Total

dan Aktivitas Antioksidan Ekstrak

Etanol Daun Kajajahi (Leucosyke capitellata Wedd). Pharmascience, 3(1), 93-100.

Syafitri, N. S., Bintang, M., Falah, S. 2014. Kandungan Fitokimia, Total Fenol, dan Total Flavonoid Ekstrak Buah Harendong (Melastoma affine D. Don). Current Biochemistry. 1(3). 105-115.

Sugrani, A., Wagner, H. 2009. Plant Drug Analysis, a Thin Layer Chromatography Atlas, second Edition, 1-365. Springer.

Ahmad, A. R., Juwita, Ratulangi, S. A. D., dan Malik, A. 2015. Penetapan Kadar Fenolik dan Flavonoid Total Ekstrak Metanol Buah dan Daun Patikala (Etlingera elatior (Jack) R.M.SM). Pharm Sci Res. 2(1). 1-10.

Nallathambya, N., Serma, L. G., Raman, J., Maleka, S. N. A., Vidyadarana, S.,, Naidua, M., Kuppusamya, U. R., \& Sabaratnama, V. 2016. Identification and in vitro Evaluation of Lipids from Sclerotia of Lignosus rhinocerotis for Antioxidant and Antineuroinflammatory Activities. Natural Product Communication. 11(10). 14851490.

Suhendi, A., Sjahid, L. A., Hanwar, D. 2011. Isolasi dan Identifikasi Flavonoid Dari Daun Dewandaru (Eugenia uniflora L.). Pharmacon, 12(2) 